\title{
Anthocyanin Degradation in Detached Pome Fruit with Reference to Preharvest Red Color Loss and Pigmentation Patterns of Blushed and Fully Red Pears
}

\author{
W.J. Steyn, ${ }^{1}$ D.M. Holcroft, ${ }^{2}$ S.J.E. Wand, and G. Jacobs \\ Department of Horticultural Science, University of Stellenbosch, Private Bag X1, Matieland 7602, \\ South Africa
}

\begin{abstract}
Additional INDEX words. Pyrus communis, high temperature, anthocyanin synthesis, pigment concentration, hue
Abstract. Exposed fruit of 'Rosemarie' blushed pear (Pyrus communis L.) displayed daily fluctuations in color in response to temperature while color was more stable in other blushed and fully red cultivars. 'Rosemarie' pears increased in redness with the passing of cold fronts, but rapidly lost red color during intermittent warmer periods. Studies on anthocyanin degradation in detached apples and pears indicated that preharvest red color loss was due to net anthocyanin degradation at high temperatures. In support, anthocyanin degradation in attached 'Rosemarie' pears corresponded with a warm period during fruit development. Susceptibility to color loss was dependent on the ability of fruit to accumulate anthocyanin. This is due to an exponential relationship between anthocyanin concentration and hue at high pigment levels and a linear relationship at lower pigment levels. Blushed and red pear cultivars that accumulate more anthocyanin with lesser dependence on climatic conditions were less susceptible to fluctuation in color.
\end{abstract}

The blushed pears (Pyrus communis L.) 'Rosemarie', 'Flamingo', and 'Forelle' constitute a fifth of the South African pear industry in terms of hectarage (Deciduous Fruit Producers Trust, 2001). Unfortunately, downgrading due to insufficient red color has limited the profitability of these pears (Huysamer, 1998). Poor fruit color has been ascribed to the loss of red color before harvest during periods of high temperature (Huysamer, 1998).

Marais et al. (2001a) found that exposure to light for $144 \mathrm{~h}$ at $37^{\circ} \mathrm{C}$ reduced the anthocyanin content of 'Cripps' Pink' apples by more than half, but anthocyanin levels remained unchanged at the same temperature if fruit were shaded. Partial shading of 'Red Bartlett' pears for 1 month before harvest reduced the loss of anthocyanins and red color occurring toward harvest in exposed fruit (Dussi et al., 1995). Light-mediated red color loss was also reported in pomerac (Syzygium malaccense) fruit stored at $5{ }^{\circ} \mathrm{C}$ (Sankat et al., 2000). Red color loss is quite common in vegetative tissues and a causal relationship with high temperatures has been observed (Oren-Shamir and Levi-Nissim, 1997).

The ready degradation of anthocyanins in food products in response to heat and light has received much research attention (Francis, 1989). However, little is known about the contribution of environmental conditions to anthocyanin degradation in attached fruit (Lancaster, 1992). Few studies have been conducted on pear color development and these have all focused on fully red pear cultivars that maintain considerable red color throughout fruit development (Dussi et al., 1997a). Color development in blushed cultivars, characterized by a red blush on an otherwise green background, has not been studied.

Received for publication 13 Mar. 2003. Accepted for publication 24 Sept. 2003. This material is based upon work supported by the National Research Foundation of South Africa under grant GUN: 2046844 and the Deciduous Fruit Producers Trust of South Africa. We also thank Pia Nel, Susan Agenbag, and Desiree de Koker for their assistance with pigment analysis, Hortec and ARC Infruitec-Nietvoorbij for supplying meteorological data, and various producers in Ceres, Grabouw, Stellenbosch, and Villiersdorp, especially Du Toit, Rocklands, and Imibala Farms, for donating fruit and providing trial sites. Any opinion, findings and conclusions or recommendations expressed in this material are those of the author(s) and do not necessarily reflect the views of the National Research Foundation.

${ }^{1}$ Corresponding author; e-mail wsteyn@sun.ac.za.

2Present address: DOLE Fresh Vegetables, P.O. Box 1759, Salinas, Calif. 93902.
We studied anthocyanin degradation in detached fruit in relation to synthesis and pigment concentration. We aimed to quantitatively confirm the occurrence of preharvest red color loss in attached fruit and establish its relation with high temperatures.

\section{Materials and Methods}

Plant material. Field trials were conducted and fruit for laboratory trials obtained from farms located in the Stellenbosch district (lat. 33 ${ }^{\circ} 58^{\prime}$ S, long. $18^{\circ} 50^{\prime} \mathrm{E}$ ) of the Western Cape region in South Africa. This region has a Mediterranean-type climate. Fully exposed fruit from the western side of north to south-orientated rows were used. We studied three blushed pears - 'Rosemarie', 'Flamingo', and 'Forelle' - and two fully red ones - 'Bon Rouge' and 'Red d'Anjou'. 'Royal Gala' and 'Cripps' Pink' apples were used to test some of the hypotheses.

Color measurement AND PIgMENT ANALYSIS. External color was measured with a chromameter (NR-3000; Nippon Denshoku, Tokyo, Japan) and anthocyanins assessed by reverse-phase high performance liquid chromatography (HP 1100; Agilent Technologies, Palo Alto, Calif.) as described in Steyn et al. (2004). Chlorophyll a and b were quantified by measuring absorption at 470, 645, and $662 \mathrm{~nm}$ on a spectrophotometer (DU Series 64; Beckman, Fullerton, Calif.) and making use of the extinction coefficients of Lichtenthaler (1987). Extraction of anthocyanin and chlorophyll was performed and samples prepared as described in Steyn et al. (2004).

SEasonal Pigmentation Patterns. The color of 30 'Rosemarie', 'Flamingo', 'Forelle', and 'Bon Rouge' pears was measured daily before $1000 \mathrm{HR}$ at the reddest position on the fruit. Trees were grafted on BP1 rootstock with the exception of 'Forelle', which was grafted on Quince A. Measurements were taken intermittently with the passing of cold fronts, from 19 Nov. 2001 (29 Nov. for 'Flamingo') until 12 Jan. 2002. Commercial harvesting commenced during the following week with the exception of 'Forelle', which was harvested toward the middle of February. Temperature data were obtained for the Nietvoorbij automatic weather station (within $4 \mathrm{~km}$ from all trial sites) and correlated with daily changes in hue. 
EFFECT OF PIGMENT CONCENTRATION ON COLOR EXPRESSION. 'Forelle' pears were harvested on 14 Feb. 2001 from an orchard established during 1998. Homogeneously colored peel disks were removed with a cork borer ( $2 \mathrm{~cm}$ in diameter) and scraped so that only pigmented layers remained ( $1 \mathrm{~mm}$ thick). Color was measured, making use of a hue neutral background, and used to divide peel disks into 18 hue groups each of $5^{\circ}$ range, from 10 to $15^{\circ}$ (dark red) to 100 to $105^{\circ}$ (yellow-green). Each group contained at least 50 disks. Anthocyanin concentrations $\left(\mu \mathrm{g}^{\cdot} \mathrm{g}^{-1}\right.$ fresh weight) were determined and plotted against hue.

ANTHOCYANIN DEGRADATION IN DETACHED FRUIT. 'Forelle' pears and 'Royal Gala' apples were taken from cold storage at $4{ }^{\circ} \mathrm{C}$ (1 and 30 Mar. 2000, respectively). Color was measured within circles marked on the reddest side of fruit, halfway between the calyx and stem ends. Marked sides of fruit of one group of 24 fruit were peeled to assess initial pigment levels. Half of the remaining fruit was placed in light-impermeable two-layered 'Fuji' wrapping bags (Kobayashi Bag Mfg., Nagano, Japan) and four six-fruit replications of covered and uncovered fruit were randomly placed in each of three growth cabinets at 10,20 , or $30 \pm 2{ }^{\circ} \mathrm{C}$, with the marked sides facing upwards. Exposed fruit were irradiated under $500 \mu \mathrm{mol} \cdot \mathrm{m}^{-2} \cdot \mathrm{s}^{-1}$ photosynthetic photon flux density (PPFD) (using a LI-189; LI-COR, Lincoln, Nebr.) provided by a single $400-\mathrm{W}$ high-pressure sodium (HPS) light (SON-T; Osram Mgbh, Munich, Germany) placed on top of the cabinets with an acrylic (Perspex) layer between the lights and fruit. After $72 \mathrm{~h}$, fruit were removed from the growth cabinets, color was measured and whole pears or the marked sides of apples peeled for pigment analysis. Initial hue of fruit placed in growth cabinets was used as covariant to compensate for differences in color at the onset of the experiment.

EFfect of Pigment CONCENTRATION ON THE RATE OF COLOR Loss. 'Royal Gala' apples were taken from cold storage at $4{ }^{\circ} \mathrm{C}$ (6 Apr. 2000) and sorted, according to the color of their reddest side, into poor, medium and well-colored groups making use of the 'Royal Gala' color chart (Set A.42; Deciduous Fruit Board, South Africa). Each group was subdivided into four replicates of 12 fruit, of which six fruit were peeled to determine the initial anthocyanin concentration. Color of the remaining fruit was measured within circles marked halfway between the calyx and stem ends before randomizing them within a growth cabinet set at $30^{\circ} \mathrm{C}$. Fruit were placed so that marked sides faced upwards. Fruit were subjected to irradiation of $500 \mu \mathrm{mol} \cdot \mathrm{m}^{-2} \cdot \mathrm{s}^{-1} P P F D$ supplied by one 400-W HPS light as described previously. After $96 \mathrm{~h}$, fruit were removed, color was measured and marked sides were peeled to assess anthocyanin concentrations.

DEgRADATION AND SYNTHESIS IN DETACHED FRUIT. An equal number of green and red 'Cripps' Pink' apples was harvested on 12 Apr. $2000, \approx 1$ week before commercial harvest, from exposed and shaded positions in an orchard established during 1998 on M793 rootstock. Fruit were stored at $4{ }^{\circ} \mathrm{C}$ until 12 June 2000. Red and green fruit were randomly divided into four groups, each of which was further subdivided into five four-fruit replications. Color was measured within circles marked halfway between the calyx and stem ends on the reddest side of red fruit and the least red side of green fruit. The marked sides of one group of each of the red and green fruit were peeled to assess initial anthocyanin concentrations ( $\mu \mathrm{g} \cdot \mathrm{g}^{-1}$ fresh weight). Replicates of the remaining six groups were randomized within three growth cabinets set up as described above and kept at 10,20 , or $30 \pm 2{ }^{\circ} \mathrm{C}$, respectively. Each growth cabinet contained one red and one green group with marked sides of fruit facing upwards. Color was measured every
$24 \mathrm{~h}$. After $168 \mathrm{~h}$, fruit were removed, marked sides were peeled and the anthocyanin concentration determined.

ANTHOCYANIN DEGRADATION IN ATTACHED FRUIT. 'Rosemarie' pears were enclosed weekly in 'Fuji' wrapping bags from five weeks before commercial harvest on 9 Jan. 2001. 'Forelle' pears were enclosed at 2-week intervals from 10 weeks before harvest on 13 Feb. 2001. At the onset of the trial, 24 control fruit of each cultivar were tagged as a reference. Fruit color was measured at enclosure and again at harvest, always at the reddest position on the fruit. After harvest, fruit were peeled and the concentration of anthocyanin, chlorophyll and total carotenoids assessed. Results were expressed as $\mu \mathrm{g} \cdot \mathrm{g}^{-1}$ fresh weight of peel.

'Rosemarie' pears from an orchard established during 1991 on BP1 rootstock were marked and collected at about weekly intervals. Collection started 49 d after full bloom (19 Nov. 1999) and continued until commercial harvest on 13 Jan. 2000. Until 25 Nov., three samples of 20 fruit each were collected, and thereafter 15 fruit per sample. Color was measured halfway between the calyx and stem ends on the light-exposed sides of fruit. Whole fruit were peeled, the peel was weighed and used to determine anthocyanin concentration $\left(\mu \mathrm{g} \cdot \mathrm{g}^{-1}\right.$ fresh weight) and anthocyanin content per fruit $(\mu \mathrm{g})$. Temperature data were obtained for the Nietvoorbij automatic weather station $( \pm 4 \mathrm{~km}$ from the trial site) and the number of hours above $28^{\circ} \mathrm{C}$ and below $14^{\circ} \mathrm{C}$ experienced during the week preceding each sampling date calculated.

STATISTICAL ANALYSIS. The data were analyzed with the general linear models (GLM), correlation (CORR), and linear regression (REG) procedures of SAS (SAS release 6.12P; SAS Institute, 1996, Cary, N.C.). The STATISTICA data analysis software system (Version 6; StatSoft Inc., Tulsa, Okla.) was used to fit nonlinear curves to data presented in Fig. 6.

\section{Results}

Seasonal pigmentation patterns. 'Rosemarie' displayed the most variation in hue $(2.7 \%$ d) of four pear cultivars studied during the 2001-02 season (Fig. 1A). The daily variance in hue of 'Forelle', 'Flamingo', and 'Bon Rouge' was $1.4^{\circ}, 1.1^{\circ}$, and $0.7^{\circ}$, respectively, and these cultivars maintained a lower hue than 'Rosemarie' throughout fruit development (Fig. 1A). Daily changes in hue of 'Rosemarie' strongly correlated with average daily temperatures (Table 1) as is also evident from the decrease in 'Rosemarie' hue in association with cold fronts and rapid increase during intermittent, warmer periods (Fig. 1B). Correlation between daily changes in 'Bon Rouge', 'Forelle', and 'Flamingo' hue and temperature parameters were generally weak (Table 1). The rate of hue decrease in 'Rosemarie' pears in response to low temperatures decreased over fruit development averaging $6.0 \%$ d between 19 and 22 Nov., 3.0\% between 29 Nov. and 4 Dec., $2.1 \%$ d between 15 and 20 Dec., $2.0 \%$ d between 4 and 8 Jan. and $1.1 \%$ d between 10 and 13 Jan. (Fig. $1 \mathrm{~A}$ and B). The rate of 'Rosemarie' hue increase during warm periods remained constant over fruit development averaging 3.3\% d between 22 and 29 Nov. and $3.2^{\circ} \mathrm{d}$ between 26 and 29 Dec. 'Rosemarie' hue on two occasions increased by more than $5^{\circ}$ within $1 \mathrm{~d}$ (Fig. 1B). 'Flamingo' and 'Bon Rouge' hue gradually increased over the experimental period, at a rate of 0.5 and $0.3 \%$, respectively (Fig. 1A).

EFFECT OF PIGMENT CONCENTRATION ON COLOR EXPRESSION. The relationship between anthocyanin concentration and hue of 'Forelle' peel disks was exponential at high anthocyanin concentrations $\left(>97 \mu \mathrm{g} \cdot \mathrm{g}^{-1}\right)$ and low hue values $\left(<40^{\circ}\right)$ (Fig. 2). The relationship became linear at lower pigment concentrations and 

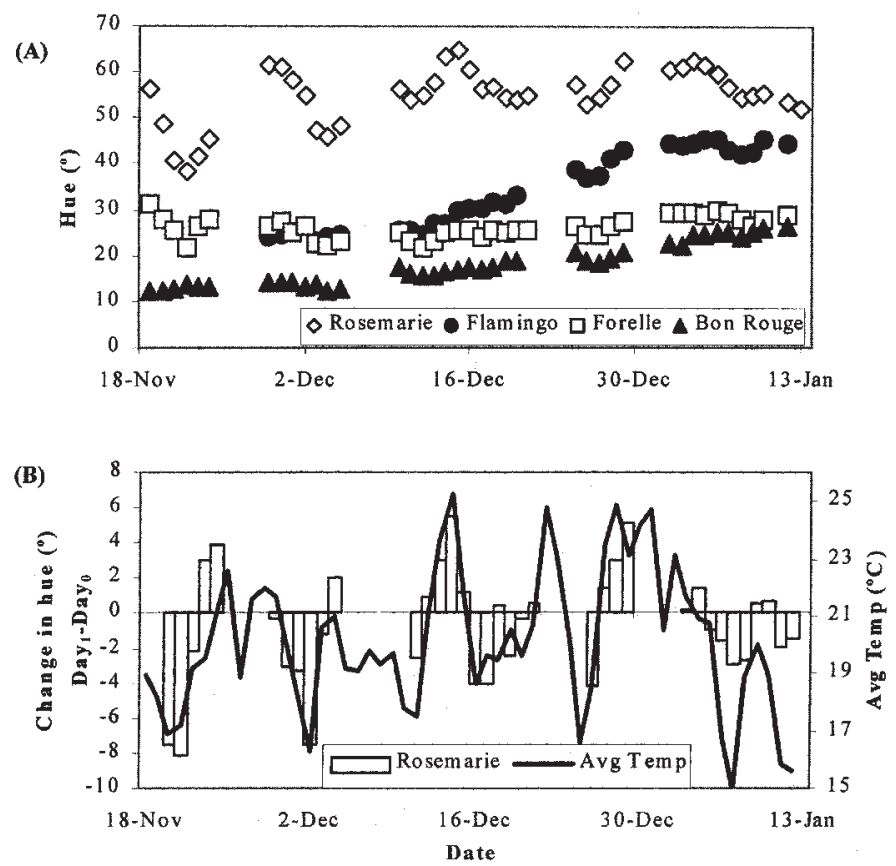

Fig. 1. Changes in the hue of 'Rosemarie', 'Flamingo', 'Forelle', and 'Bon Rouge' pears measured daily from 19 Nov. 2001 to 13 Jan. 2002 (A). Daily changes in the hue of 'Rosemarie' and average daily temperatures are presented in $(\mathbf{B})$. Hue angles reported fluctuate between $0^{\circ}$ (red-purple) and $90^{\circ}$ (yellow).

higher hue-values. The chlorophyll concentration of peel disks was constant over the hue range studied (data not presented).

ANTHOCYANIN DEGRADATION IN DETACHED FRUIT. Anthocyanin degradation increased linearly between 10 to $30^{\circ} \mathrm{C}$ in both 'Forelle' pears and 'Royal Gala' apples (Figs. 3 and 4). Light increased the rate of anthocyanin degradation in 'Royal Gala' (Fig. 4), but not 'Forelle' (Fig. 3). Red color loss, as evidenced by an increase in hue, increased linearly with increasing temperature in 'Forelle' (Fig. 3) and in irradiated, but not shaded 'Royal Gala' (Fig. 4B). Anthocyanin concentration of 'Forelle' and 'Royal Gala' fruit kept at $30{ }^{\circ} \mathrm{C}$ decreased by $62 \%$ and $40 \%$, respectively, compared to the control group of fruit peeled at the onset of the experiment. However, hue increased by only $6.4^{\circ}$ and $4.2^{\circ}$, respectively.

EFFECT OF ANTHOCYANIN CONCENTRATION ON THE RATE OF COLOR LOSS. Hue increased nearly 13 times faster in 'Royal Gala' fruit of poor red color and low anthocyanin concentration than in well-colored fruit with a high anthocyanin concentration when irradiated for $96 \mathrm{~h}$ at $30^{\circ} \mathrm{C}$ (Table 2; Fig. 5). However, the absolute reduction in the anthocyanin concentration was much greater in the well-colored fruit $\left(64 \mu \mathrm{g} \cdot \mathrm{g}^{-1}\right.$ compared to $\left.25 \mu \mathrm{g} \cdot \mathrm{g}^{-1}\right)$ (Table 2).

DEGRADATION AND SYNTHESIS IN DETACHED FRUIT. Hue of green 'Cripps' Pink' fruit kept at 10 and $30{ }^{\circ} \mathrm{C}$ slowly decreased from 114 to $95^{\circ}$ over the $168 \mathrm{~h}$ experimental period, but the anthocyanin concentration of fruit did not increase significantly (Fig. 6A and B). However, the hue of green fruit kept at $20{ }^{\circ} \mathrm{C}$ decreased to $58^{\circ}$ as a result of anthocyanin synthesis. As found with green fruit, the anthocyanin concentration of red fruit kept at $20^{\circ} \mathrm{C}$ also increased, but the increase was smaller $\left(17 \mu \mathrm{g} \cdot \mathrm{g}^{-1}\right.$ compared to 43 $\mu \mathrm{g} \cdot \mathrm{g}^{-1}$ ) and hue remained unchanged at $\approx 45^{\circ}$ (Fig. 6A). The hue and anthocyanin concentration of red fruit kept at $10^{\circ} \mathrm{C}$ did not change significantly. The hue of red fruit kept at $30^{\circ} \mathrm{C}$ increased by $20^{\circ}$ and this was accompanied by a $74 \%\left(43 \mu \mathrm{g} \cdot \mathrm{g}^{-1}\right)$ reduction in anthocyanin concentration (Fig. 6A and B).

ANTHOCYANIN DEGRADATION IN ATTACHED FRUit. Anthocyanin
Table 1. Correlation of daily changes in hue of 'Rosemarie', 'Flamingo', 'Forelle', and 'Bon Rouge' pears as repetitively measured at the reddest position on the same fruit between 19 Nov. 2001 and 12 Jan. 2002 with daily maximum, minimum and average temperatures. Daily changes in hue were determined by subtracting hue values of the previous day from hue values of the current day. A decrease in hue indicates an increase in redness from one day to the next while an increase in hue indicates a decrease in redness.

\begin{tabular}{lccc}
\hline & \multicolumn{3}{c}{ Correlation coefficient $(r)^{\mathrm{z}}$} \\
\cline { 2 - 4 } & Daily & Daily & Avg \\
& $\max$ & $\min$ & daily \\
temp & temp & temp \\
Cultivar & $\left({ }^{\circ} \mathrm{C}\right)$ & $0.54^{* * *}$ & $0.74^{* * *}$ \\
\hline Rosemarie & $0.65^{* * *}$ & $0.57^{* *}$ & $0.55^{* *}$ \\
Flamingo & $0.48^{*}$ & $0.37^{*}$ & $0.42^{*}$ \\
Forelle & 0.30 & $0.45^{* *}$ & 0.19 \\
Bon Rouge & 0.13 & $\left.{ }^{\circ} \mathrm{C}\right)$ \\
\hline
\end{tabular}

'Pearson correlation coefficients $/ P>|\mathrm{R}|$ under Ho: Rho $=0 / \mathrm{N}$ where $\mathrm{N}=36,35,34$, and 26 for 'Rosemarie', 'Forelle', 'Bon Rouge', and 'Flamingo', respectively.

*********agnificant correlation coefficient at $P=0.05,0.01$, or 0.001 , respectively.

concentration and red color of 'Rosemarie' and 'Forelle' fruit enclosed in 'Fuji' wrapping bags rapidly decreased as duration of enclosure increased (Fig. 7A and B). Chlorophyll concentration also decreased, but at a much slower rate than anthocyanin concentration. Total carotenoid concentration decreased in 'Rosemarie' (Fig. 7A), but not 'Forelle' (Fig. 7B). While peel mass of 'Rosemarie' fruit more or less doubled during the study (data not presented), anthocyanin concentration decreased nearly 20 times. It took about twice as long for red color to disappear completely from 'Forelle' compared to 'Rosemarie' peel (Fig. 7A and B).

Anthocyanin concentration and red color of 'Rosemarie' pears, which were generally poor throughout fruit development, transiently increased between 19 and 26 Nov. when a cold front interrupted the exceptionally hot weather experienced throughout the 1999-2000 season (Fig. 8A and B). Fruit accumulated $\approx 30 \mu \mathrm{g}$ anthocyanin resulting in an increase in anthocyanin concentration from $\approx 4 \mu \mathrm{g} \cdot \mathrm{g}^{-1}$ to just below $11 \mu \mathrm{g} \cdot \mathrm{g}^{-1}$ and a decrease in hue from $73^{\circ}$ to just below $50^{\circ}$ (Fig. 8A). After the cold front had passed, the anthocyanin content of fruit rapidly decreased so that after 2 weeks fruit contained 54\% less anthocyanin. During this same period, hue increased at an average rate of $1.6 \% \mathrm{~d}$ while anthocyanin concentration decreased at a rate of $0.45 \mu \mathrm{g} \cdot \mathrm{g}^{-1} \cdot \mathrm{d}^{-1}$. A dilu-

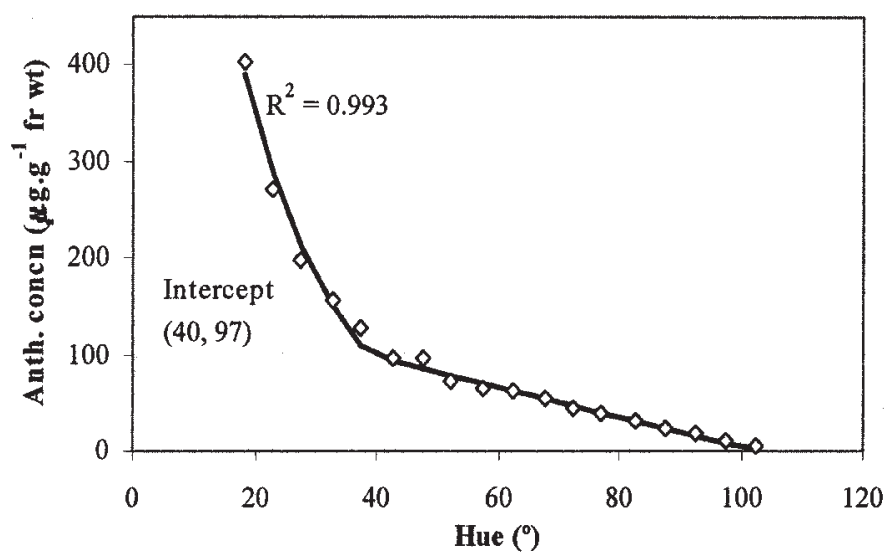

Fig. 2. Relationship between hue and anthocyanin concentration in 'Forelle' peel disks grouped into 18 hue groups each of $5^{\circ}$ ranging from 10 to $15^{\circ}$ (red) to 100 to $105^{\circ}$ (yellow-green). 


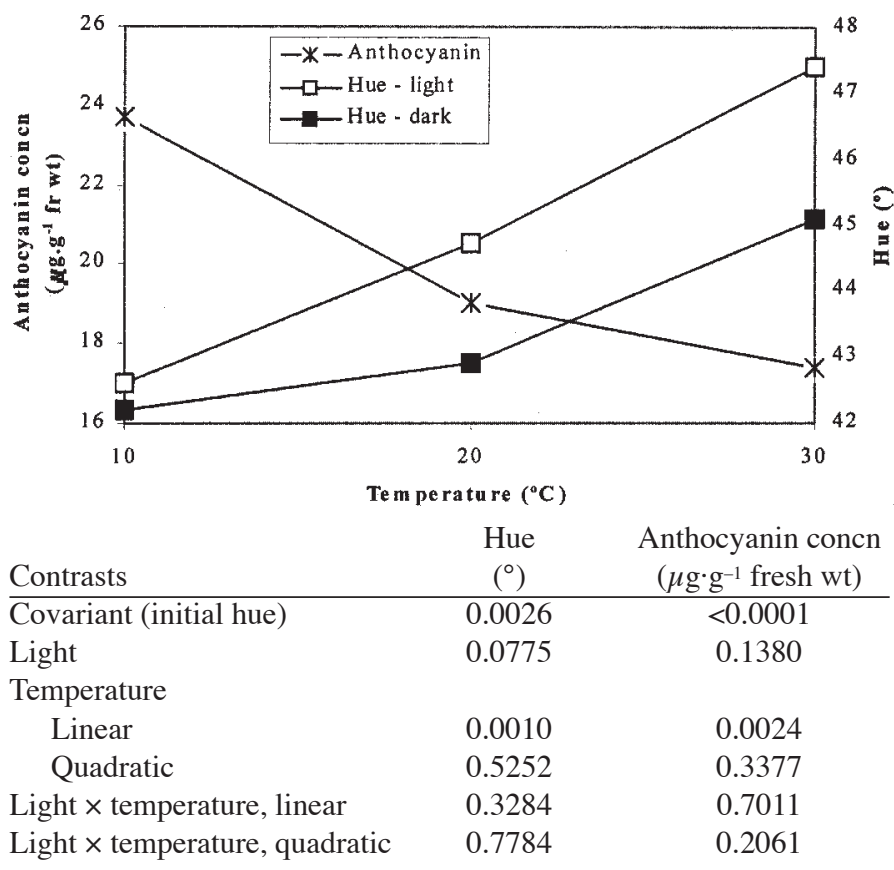

Fig. 3. Changes in the hue and anthocyanin concentration of 'Forelle' pear peel exposed for $72 \mathrm{~h}$ to moderate high-pressure sodium light $\left(500 \mu \mathrm{mol} \cdot \mathrm{m}^{-2} \cdot \mathrm{s}^{-1}\right)$ at 10,20 , or $30^{\circ} \mathrm{C}$. Since irradiation had no effect on anthocyanin concentrations, only the temperature effect is presented. Increasing hue angles denote a reduction in redness. Means, separated by LSD (5\%), are adjusted for hue at $0 \mathrm{~h}$.

tion rate of $0.24 \mu \mathrm{g} \cdot \mathrm{g}^{-1} \cdot \mathrm{d}^{-1}$ anthocyanin was calculated from the increase in the fresh mass of fruit peel over this period. Hereafter, the anthocyanin content and hue of fruit remained constant until the week before harvest while temperatures remained high over this period. Anthocyanin content of fruit decreased and the hue increased in the week before harvest though temperatures were mild and fewer hours above $28{ }^{\circ} \mathrm{C}$ were accumulated.

\section{Discussion}

Anthocyanin degradation. Marais et al. (2001a) found that irradiation for $144 \mathrm{~h}$ at $37^{\circ} \mathrm{C}$ reduced the anthocyanin content of detached 'Cripps' Pink' apples by more than half, resulting in red color loss. Results of the current study on 'Forelle' pears and 'Royal Gala' apples confirmed that high temperatures (30 ${ }^{\circ} \mathrm{C}$ ) accelerate the degradation of anthocyanin and the fading of red color in detached fruit (Figs. 3 and 4). In contrast to the results of Marais et al. (2001a), light was not a prerequisite for anthocyanin degradation (Figs. 3 and 4), though it increased the rate of anthocyanin degradation and color loss in 'Royal Gala' apples (Fig. 4). Though little is known about the mechanism of anthocyanin degradation in fruit (Lancaster, 1992), color changes
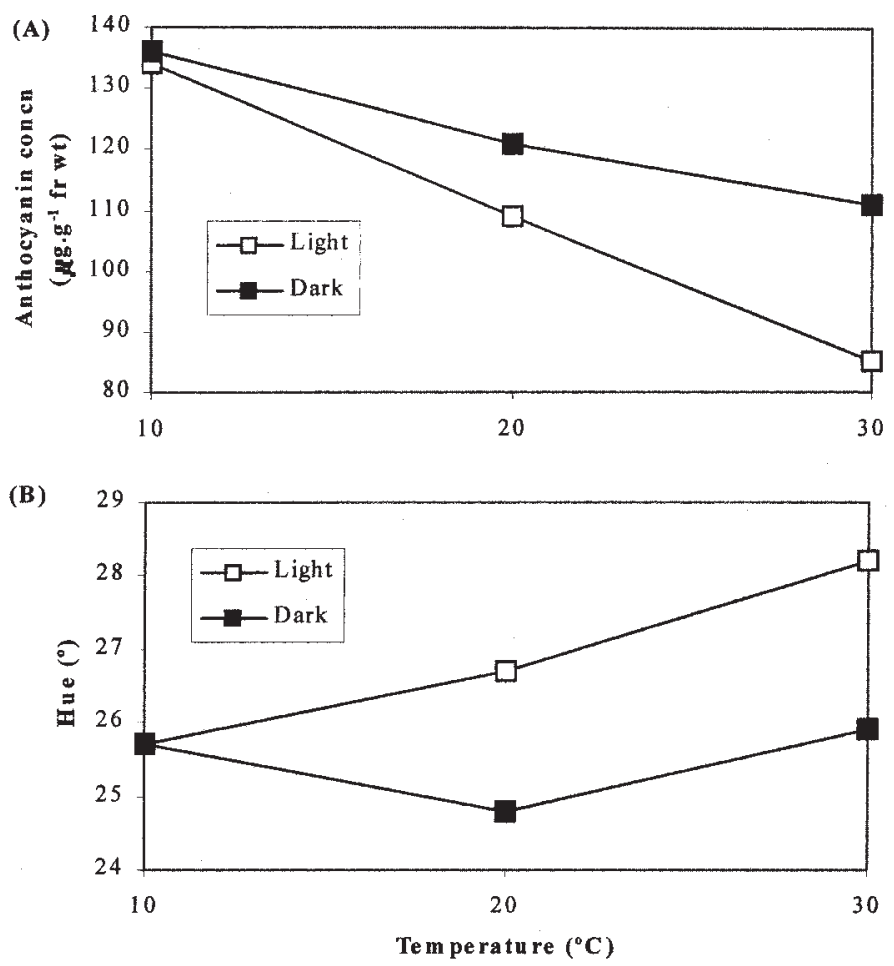

\begin{tabular}{lcc} 
Contrasts & $\begin{array}{c}\text { Hue } \\
\left(^{\circ}\right)\end{array}$ & $\begin{array}{c}\text { Anthocyanin concn } \\
\left(\mu \mathrm{g} \cdot \mathrm{g}^{-1} \text { fresh wt }\right)\end{array}$ \\
\hline Covariant (initial hue) & 0.0078 & 0.0008 \\
Light & 0.0008 & 0.0288 \\
Temperature & & \\
$\quad$ Linear & 0.0063 & 0.0001 \\
$\quad$ Quadratic & 0.1039 & 0.8559 \\
Light $\times$ temperature, linear & 0.0136 & 0.1028 \\
Light $\times$ temperature, quadratic & 0.2928 & 0.8260 \\
\hline
\end{tabular}

Fig. 4. Changes in anthocyanin concentration (A) and in hue (B) of 'Royal Gala' apple peel exposed for $72 \mathrm{~h}$ to moderate high-pressure sodium light (500 $u \mathrm{~mol} \cdot \mathrm{m}^{-2 \cdot \mathrm{s}^{-1}}$ ) at 10,20 , or $30^{\circ} \mathrm{C}$. Increasing hue angles denote a reduction in redness. Means, separated by LSD (5\%), are adjusted for hue at $0 \mathrm{~h}$.

in food products have received much research attention.

Due to their reactive structure, anthocyanins are readily degraded in food products in response to heat and light (Francis, 1989). Degradation may be nonenzymatic, but may also be mediated by common enzyme groups, i.e., the glycosidases, polyphenoloxidases and peroxidases (Francis, 1989; Piffaut et al., 1994). Piffaut et al. (1994) found that anthocyanin degradation mediated by B-glycosidases or induced by high temperature proceeded via the same pathway. Radiant heating might contribute to anthocyanin degradation by increasing fruit peel temperature

Table 2. Change in the hue and anthocyanin concentration in peel of 'Royal Gala' apples, subdivided according to initial red color into good, medium and poorly colored groups, irradiated $\left(500 \mu \mathrm{mol} \cdot \mathrm{m}^{-2} \cdot \mathrm{s}^{-1}\right)$ for $96 \mathrm{~h}$ at $30^{\circ} \mathrm{C}$.

\begin{tabular}{|c|c|c|c|c|c|c|}
\hline $\begin{array}{l}\text { Fruit } \\
\text { color }\end{array}$ & $\begin{array}{l}\text { Initial } \\
\text { hue } \\
\left({ }^{\circ}\right)\end{array}$ & $\begin{array}{l}\text { Final } \\
\text { hue } \\
\left({ }^{\circ}\right)\end{array}$ & $\begin{array}{c}\text { Increase } \\
\text { in hue } \\
\left({ }^{\circ}\right)\end{array}$ & $\begin{array}{c}\text { Initial } \\
\text { anthocyanin } \\
\text { concn } \\
\left(\mu \mathrm{g} \cdot \mathrm{g}^{-1} \text { fresh } \mathrm{wt}\right)\end{array}$ & $\begin{array}{c}\text { Final } \\
\text { anthocyanin } \\
\text { concn } \\
\left(\mu \mathrm{g} \cdot \mathrm{g}^{-1} \text { fresh } \mathrm{wt}\right)\end{array}$ & $\begin{array}{c}\text { Change in } \\
\text { anthocyanin } \\
\text { concn } \\
\left(\mu \mathrm{g} \cdot \mathrm{g}^{-1} \text { fresh wt }\right)\end{array}$ \\
\hline Medium & $31.8 \mathrm{~b}$ & $44.0 \mathrm{~b}$ & $12.2 \mathrm{~b}$ & $76.3 \mathrm{~b}$ & $36.5 \mathrm{~b}$ & $39.8 \mathrm{~b}$ \\
\hline Poor & $55.9 \mathrm{c}$ & $75.1 \mathrm{c}$ & $19.2 \mathrm{a}$ & $41.2 \mathrm{c}$ & $16.0 \mathrm{c}$ & $25.3 \mathrm{~b}$ \\
\hline$P>\mathrm{F}$ & 0.0001 & 0.0001 & 0.0001 & 0.0001 & 0.0001 & 0.0035 \\
\hline
\end{tabular}

${ }^{2}$ Means in columns were separated by LSD (5\%). 


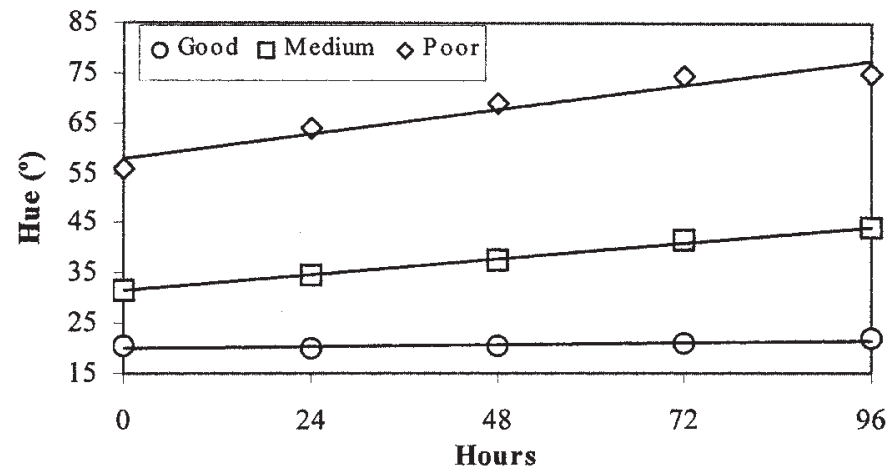

\begin{tabular}{lcc}
$\begin{array}{l}\text { Color } \\
\text { group }\end{array}$ & $\begin{array}{c}\text { Gradient } \\
\left({ }^{\circ} \mathrm{h}^{-1}\right)\end{array}$ & $\begin{array}{c}\text { Y-intercept } \\
\left({ }^{\circ}\right)\end{array}$ \\
\hline Good & $0.016 \mathrm{c}^{\mathrm{z}}$ & $20.10 \mathrm{c}$ \\
Medium & $0.132 \mathrm{~b}$ & $31.60 \mathrm{~b}$ \\
Poor & $0.205 \mathrm{a}$ & $57.80 \mathrm{a}$ \\
$P>\mathrm{F}$ & 0.0001 & 0.0001 \\
\hline
\end{tabular}

${ }^{\mathrm{z}}$ Means in columns separated by LSD (5\%).

Fig. 5. Changes in the hue of good, medium and poorly colored groups of 'Royal Gala' apples subjected for $96 \mathrm{~h}$ to moderate high-pressure sodium light (500 $\left.\mu \mathrm{mol} \cdot \mathrm{m}^{-2} \cdot \mathrm{s}^{-1}\right)$ at $30{ }^{\circ} \mathrm{C}$. Increasing hue angles denote a reduction in redness. Means were separated by LSD (5\%).

(A)

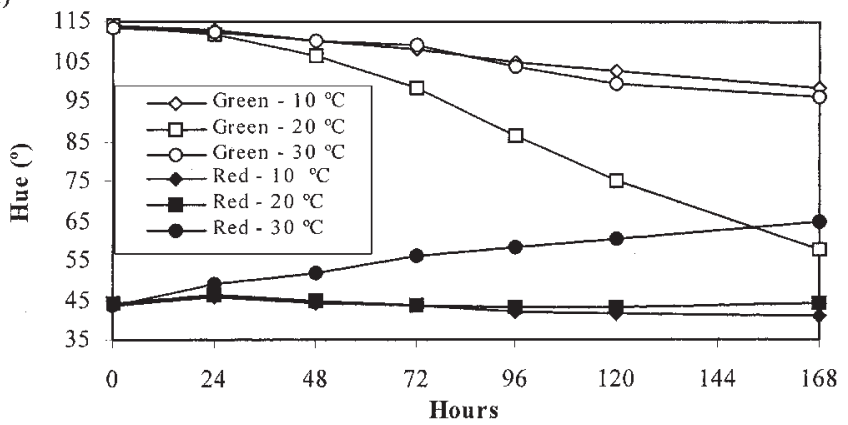

(B)

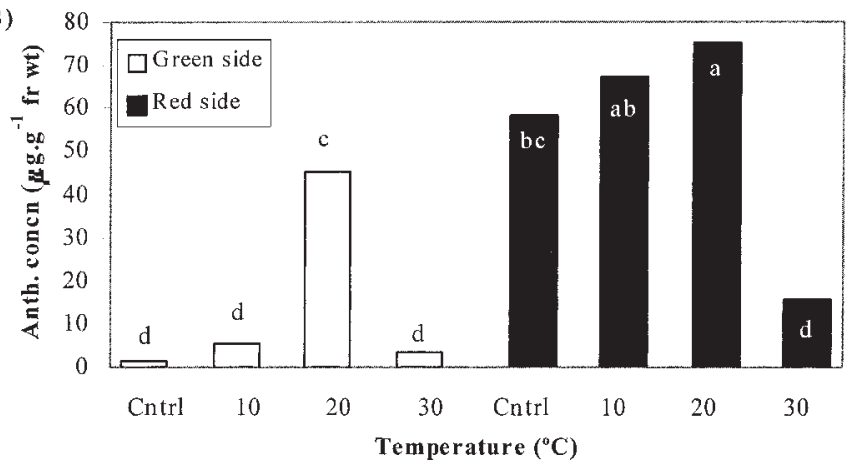

\begin{tabular}{lcc} 
Contrasts & $\begin{array}{c}\text { Hue } \\
\left({ }^{\circ}\right)\end{array}$ & $\begin{array}{c}\text { Anthocyanin concn } \\
\left(\mu \mathrm{g} \cdot \mathrm{g}^{-1} \text { fresh wt }\right)\end{array}$ \\
\hline Color & 0.0001 & 0.0001 \\
Temperature & & \\
$\quad$ Linear & 0.0001 & 0.0001 \\
$\quad$ Quadratic & 0.0001 & 0.0001 \\
Color $\times$ temperature, linear & 0.0001 & 0.0113 \\
Color $\times$ temperature, quadratic & 0.0521 & 0.0009
\end{tabular}

Fig. 6. Changes in the hue (A) and anthocyanin concentration (B) of initially red or green 'Cripps' Pink' apple peel exposed for $168 \mathrm{~h}$ to moderate high-pressure sodium light $\left(500 \mu \mathrm{mol} \cdot \mathrm{m}^{-2} \cdot \mathrm{s}^{-1}\right)$ at 10,20 , or $30^{\circ} \mathrm{C}$. Increasing hue angles denote a reduction in redness. Means were separated by LSD (5\%). by up to $15^{\circ} \mathrm{C}$ at high ambient temperatures (Smart and Sinclair, 1976). Evaporative cooling by pulsed overhead irrigation, which is known to act by negating radiant heating of the fruit surface (Unrath, 1972), reduced the fading of 'Rosemarie' (Steyn et al., unpublished data) and 'Sensation Red Bartlett' (Dussi et al., 1997b) pear color during warm days. However, light-mediated red color loss in pomerac fruit (Syzygium malaccense) was observed at $5{ }^{\circ} \mathrm{C}$ (Sankat et al., 2000), suggesting that light might have a direct effect on degradation. Since we took care to prevent radiant heating, the light-mediated degradation of anthocyanin in 'Royal Gala' apples is probably a direct effect of light (Fig. 4). Attoe and Von Elbe (1981) suggested that light increases the reactivity of the anthocyanin molecule and so contributes to its degradation.

Involvement of light in degradation seems to be at odds with its requirement for anthocyanin synthesis. However, light-mediated degradation of anthocyanin at mild temperatures is probably insignificant compared to the stimulating effect of light on anthocyanin synthesis.

DEGRADATION AND SYNTHESIS. Our results indicated that fruit color is determined by the interaction between anthocyanin synthesis and degradation at different temperatures. The optimum
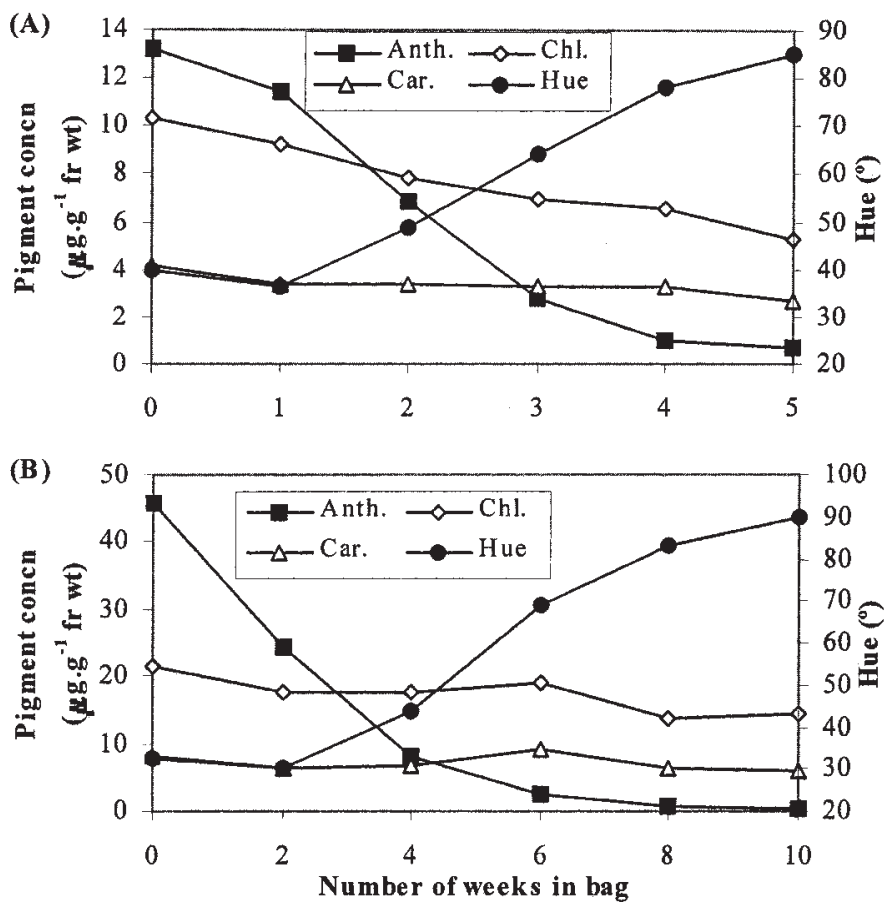

Hue Anthocyanin Chlorophyll Carotenoids

\begin{tabular}{lcccc} 
Contrasts & $\left(^{\circ}\right)$ & \multicolumn{3}{c}{$\left(\mu \mathrm{g} \cdot \mathrm{g}^{-1}\right.$ fresh wt $)$} \\
\cline { 3 - 5 } Rosemarie & & & & \\
$\quad$ Linear & 0.0001 & 0.0001 & 0.0014 & 0.0403 \\
$\quad$ Quadratic & 0.0190 & 0.0332 & 0.7489 & 0.7891 \\
$\quad$ Cubic & 0.0016 & 0.0385 & 0.7536 & 0.3266 \\
Forelle & & & & \\
$\quad$ Linear & 0.0001 & 0.0001 & 0.0129 & 0.8893 \\
$\quad$ Quadratic & 0.0001 & 0.0078 & 0.8612 & 0.9555 \\
$\quad$ Cubic & 0.0284 & 0.9016 & 0.0585 & 0.0373 \\
\hline
\end{tabular}

Fig. 7. Changes in the hue and the anthocyanin, chlorophyll and total carotenoid concentration of 'Rosemarie' (A) and 'Forelle' (B) pears enclosed in light impermeable bags from 5 or 10 weeks before harvest, respectively. Increasing hue angles denote a reduction in redness. 

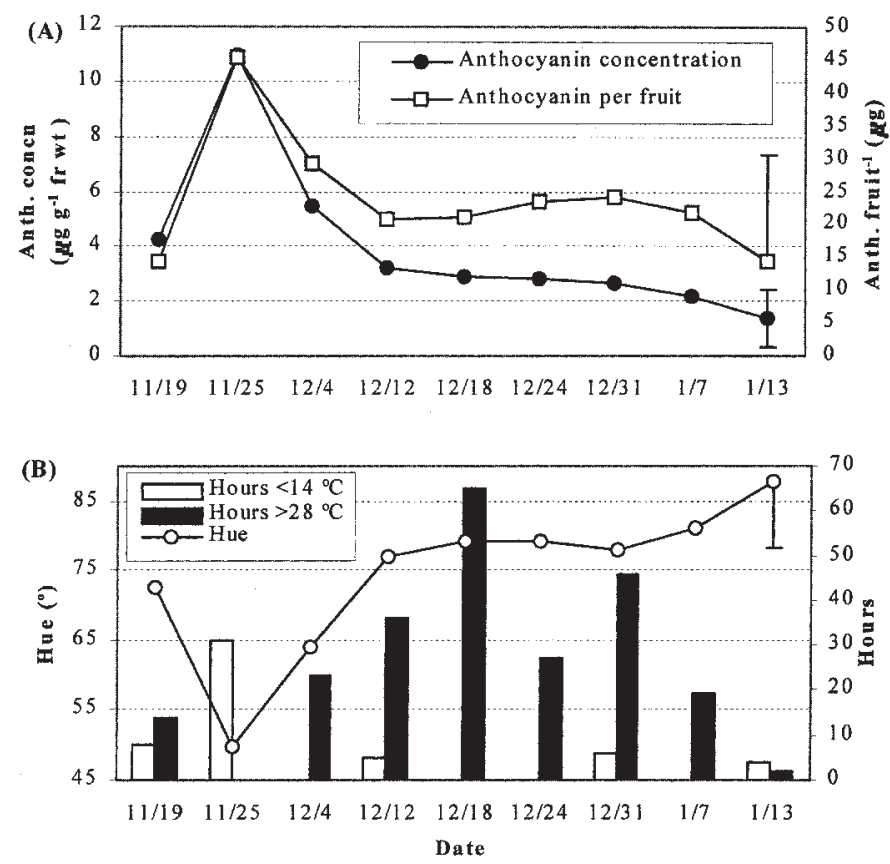

Fig. 8. Changes in the anthocyanin concentration and content of 'Rosemarie' pears during 1999-2000 from 49 d after full bloom (19 Nov. 1999) until commercial harvest (13 Jan. 2000) are presented in (A). Changes in hue and the number of hours below $14{ }^{\circ} \mathrm{C}$ or above $30{ }^{\circ} \mathrm{C}$ experienced over the $6 \mathrm{~d}$ before sampling of fruit are presented in (B). Hue angles reported fluctuate between $0^{\circ}$ (redpurple) and $90^{\circ}$ (yellow).

temperature for anthocyanin synthesis in mature fruit of different apple cultivars varies between 20 and $25^{\circ} \mathrm{C}$, with synthesis decreasing at lower and higher temperatures Curry (1997). On the other hand, anthocyanin degradation increased linearly between 10 and $30^{\circ} \mathrm{C}$ in both 'Royal Gala' apples and 'Forelle' pears (Figs. 3 and 4). Hence, the anthocyanin concentration of mature, red 'Cripps' Pink' apples was stable at $10^{\circ} \mathrm{C}$ where both synthesis and degradation were low, increased at $20^{\circ} \mathrm{C}$ where synthesis exceeded degradation and decreased at $30{ }^{\circ} \mathrm{C}$ where degradation was greater than synthesis (Fig. 6B). Degradation and color loss in detached 'Forelle' and 'Royal Gala' also occurred at $20{ }^{\circ} \mathrm{C}$, albeit at a slower rate (Figs. 3 and 4). Net anthocyanin degradation at $20{ }^{\circ} \mathrm{C}$ in these fruit is probably explained by the inability of mature pears to accumulate anthocyanin from the tree (Marais et al., 2001b) and the reduction of synthesis in postclimacteric apples (Curry, 1997).

It follows that pigmentation can be expected to fluctuate in response to temperature in attached fruit, increasing when mild temperature favors synthesis and decreasing when the rate of anthocyanin degradation exceeds synthesis at high temperatures. Of course the endogenous regulation of anthocyanin synthesis during fruit development would determine the general pigmentation pattern of fruit. Factors that reduce the rate of anthocyanin synthesis, such as substrate limitation, would decrease the temperature at which net anthocyanin degradation and color loss occur. Expression of anthocyanin pigmentation in vegetative tissues (Christie et al., 1994) as well as in many crops, e.g., apples (Curry, 1997) generally requires induction at low temperatures. High temperatures have been found to inhibit the induction of anthocyanin synthesis (Reay, 1999). Optimal day temperature for anthocyanin synthesis does not change in the absence of induction, but the rate of anthocyanin synthesis is reduced (Curry, 1997). Consequently, high temperatures could contribute to red color loss by preventing or inhibiting the induction of anthocyanin synthesis and by reducing the rate of anthocyanin synthesis when induced. High anthocyanin concentrations reduced the ability of red compared to green 'Cripps' Pink' fruit to further accumulate anthocyanin (Fig. 6B). Lancaster et al. (2000) found a similar reduction in the ability of apple cultivars or fruit with high anthocyanin concentrations to accumulate anthocyanin at 10 and $20^{\circ} \mathrm{C}$ and attributed this effect to either previous light exposure or the genetic background of fruit. Because of the reduction in the rate of anthocyanin synthesis in red fruit, net anthocyanin degradation should occur at a lower temperature compared to less red fruit of the same cultivar, but this was not investigated. The manner in which high anthocyanin concentration limits further accumulation, whether it is by reducing light levels, desensitization of the signaling pathway or feedback inhibition, remains to be determined. Anthocyanin levels are tightly regulated to modulate light absorption in accordance with environmental and developmental requirements (Pietrini and Massacci, 1998).

EFFECT OF PIGMENT CONCENTRATION ON COLOR EXPRESSION. The extent of color change in response to anthocyanin synthesis or degradation was found to depend on the anthocyanin concentration of peel. If comparable rates of anthocyanin degradation are assumed, fruit containing little anthocyanin should lose red color ahead of fruit containing more anthocyanin. However, due to the exponential relationship between hue and anthocyanin concentration at high concentrations (Fig. 2), much greater changes in pigment concentration are required to induce comparable changes in the hue of red compared to less red fruit. This principle was illustrated in 'Royal Gala' apples where red color loss at $30{ }^{\circ} \mathrm{C}$ occurred much faster in poorly colored apples containing little anthocyanin than in well-colored fruit containing large amounts of anthocyanin (Fig. 5) even though the well-colored fruit lost more anthocyanin (Table 2). Similarly, the hue of initially red 'Cripps' Pink' apples did not change while, in contrast, the hue of initially green 'Cripps' Pink' apples decreased by $56^{\circ}$ during accumulation of anthocyanin at $20^{\circ} \mathrm{C}$ (Fig. 6A). The effect of pigment concentration on the rate of color loss also explains the relatively small increases in the hue of 'Royal Gala' and 'Forelle' fruit in response to the considerable degradation of anthocyanin (Figs. 3 and 4).

DEGRADATION IN ATTACHED FRUIT. Rapid degradation of anthocyanin in attached 'Rosemarie' and 'Forelle' pears was revealed by enclosing fruit in light-impermeable bags, which prevented anthocyanin synthesis (Fig. 7). Fully exposed 'Rosemarie' pears also underwent red color loss during a warm 2-week period in early December, $\approx 1$ month before harvest during the 1999-2000 season (Fig. 8B). Though dilution contributed to the reduction in the anthocyanin concentration of the pears, the amount of anthocyanin per fruit decreased by $>50 \%$ indicating the contribution of net degradation of anthocyanin to color loss (Fig. 8A). Red color loss and net anthocyanin degradation also occurred in the two weeks before the harvest of 'Rosemarie' pears even though temperatures were milder than earlier during fruit development (Fig. 8A and B). The reason for this further loss of color is uncertain. Color loss appeared to be distinct from poor color development due to insufficient light exposure since it occurred in fruit exposed to full sunlight. The involvement of light in color loss was not investigated. However, partial shading of 'Red Bartlett' pears reduced the fading of red color that occurred during the month before harvest (Dussi et al., 1995).

The association of anthocyanin degradation and color loss in 'Rosemarie' with high temperatures (Fig. 8B) is consistent 
with grower reports (Huysamer, 1998) and with our observations of anthocyanin degradation and color loss in detached fruit (Figs. 3, 4, and 6). Fading of red color in immature 'Jonathan' apples was also associated with high temperatures, but since total anthocyanin per fruit was not presented, it is impossible to determine whether color loss was due to dilution or degradation (Faragher, 1983). A causal relationship with high temperatures has been observed in vegetative tissues where red color loss is quite common (Oren-Shamir and Levi-Nissim, 1997). However, in at least some plants, anthocyanin degradation seems to have a definite developmental component with little involvement of temperature and light. In the resurrection plant Craterostigma wilmsii, for example, anthocyanins decreased to levels before dehydration within $24 \mathrm{~h}$ after rehydration (Sherwin and Farrant, 1998). Since increases in the hue of 'Rosemarie' pears in response to high temperatures were comparable at different stages of fruit development (Fig. 1B), anthocyanin degradation does not seem to be under developmental control.

Pigmentation Patterns in different Pear Cultivars. 'Rosemarie' red color fluctuated considerably during fruit development in response to temperature while the color of 'Bon Rouge', 'Flamingo', and 'Forelle' was more stable and less responsive to temperature (Table 1; Fig. 1). These differences can be interpreted according to the foregoing discussion of anthocyanin degradation in relation to synthesis and pigment concentration.

Anthocyanin synthesis in 'Rosemarie' requires low temperatures and fruit gain red color with the passing of cold fronts (Table 1, Fig. 1B) (Steyn et al., 2004). However, during intermittent warmer periods, red color fades due to reduced anthocyanin synthesis, increased anthocyanin degradation and, to a lesser extent, dilution. Evidently, even a single hot day could bring about considerable red color loss (Fig. 1B). 'Rosemarie' possesses the lowest capacity for anthocyanin accumulation of all the red and blushed pear cultivars grown in South Africa (Steyn et al., 2004), making it more susceptible to large fluctuations in color and red color loss.

The stability of red color in 'Bon Rouge', 'Flamingo', and 'Forelle' could be due to continuation of anthocyanin synthesis regardless of temperature. In support, analysis of enzyme activity indicated that anthocyanin synthesis in 'Bon Rouge' did not require low temperatures (Steyn et al., 2004). However, in light of the high pigment concentrations accumulated in these cultivars (Steyn et al., 2004), even considerable anthocyanin synthesis or degradation might have little effect on red color. The faster rate of color fading toward harvest in 'Flamingo' compared to 'Bon Rouge' (Fig. 1A) is probably due to the lower capacity for anthocyanin synthesis in 'Flamingo' (Steyn et al., 2004).

\section{Literature Cited}

Attoe, E.L. and J.H. Von Elbe. 1981. Photochemical degradation of betanine and selected anthocyanins. J. Food Sci. 46:1934-1937.

Christie, P.J., M.R. Alfenito, and V. Walbot. 1994. Impact of low-temperature stress on general phenylpropanoid and anthocyanin pathways:
Enhancement of transcript abundance and anthocyanin pigmentation in maize seedlings. Planta 194:541-549.

Curry, E.A. 1997. Temperatures for optimal anthocyanin accumulation in apple tissue. J. Hort. Sci. 72:723-729.

Deciduous Fruit Producers Trust. 2001. Key deciduous fruit statistics 2001. Deciduous Fruit Producers Trust, Paarl, South Africa.

Dussi, M.C., D. Sugar, A.N. Azarenko, and T.L. Righetti. 1997a. Colorimetric characterization of red pear cultivars. Fruit Var. J. 51:39-43.

Dussi, M.C., D. Sugar, A.N. Azarenko, and T.L. Righetti. 1997b. Effects of cooling by over-tree sprinkler irrigation on fruit color and firmness in 'Sensation Red Bartlett' pear. HortTechnology 7:55-57.

Dussi, M.C., D. Sugar, and R.E. Wrolstad. 1995. Characterizing and quantifying anthocyanins in red pears and the effect of light quality on fruit color. J. Amer. Soc. Hort. Sci. 120:785-789.

Faragher, J.D. 1983. Temperature regulation of anthocyanin accumulation in apple skin. J. Expt. Bot. 34:1291-1298.

Francis, F.J. 1989. Food colorants: Anthocyanins. Crit. Rev. Food Sci. Nutr. 28:273-314.

Huysamer, M. 1998. Report of the blushed pear workgroup: Perceptions, facts and questions, p. 187-192. Proc. Cape Pomol. Assn. Tech. Symp., Cape Town, South Africa, 2-3 June.

Lancaster, J.E. 1992. Regulation of skin colour in apples. Crit. Rev. Plant Sci. 10:487-502.

Lancaster, J.E., P.F. Reay, J. Norris, and R.C. Butler. 2000. Induction of flavonoids and phenolic acids in apple by UV-B and temperature. J. Hort. Sci. Biotechnol. 75:142-148.

Lichtenthaler, H.K. 1987. Chlorophylls and carotenoids: pigments of photosynthetic biomembranes. Meth. Enzymol. 148:350-382.

Marais, E., G. Jacobs, and D.M. Holcroft. 2001a. Colour response of 'Cripps'Pink' apples to postharvest irradiation is influenced by maturity and temperature. Scientia Hort. 90:31-41.

Marais, E., G. Jacobs, and D.M. Holcroft. 2001b. Postharvest irradiation enhances anthocyanin synthesis in apples but not in pears. HortScience 36:738-740.

Oren-Shamir, M. and A. Levi-Nissim. 1997. Temperature effects on the leaf pigmentation of Continus coggygria 'Royal Purple'. J. Hort. Sci. 72:425-432.

Pietrini F., and A.Massacci. 1998. Leaf anthocyanin content changes in Zea mays L. grown at low temperature: Significance for the relationship between quantum yield of PS II and the apparent quantum yield of $\mathrm{CO}_{2}$ assimilation. Photosyn. Res. 58:213-219.

Piffaut, B., F. Kader, M. Girardin, and M. Metche. 1994. Comparative degradation pathways of malvidin 3,5-diglucoside after enzymatic and thermal treatments. Food Chem. 50:115-120.

Reay, P.F. 1999. The role of low temperatures in the development of the red blush on apple fruit ('Granny Smith'). Scientia Hort. 79:113-119.

Sankat, C.K.,A. Basanta and V. Maharaj. 2000. Light mediated red colour degradation of the pomarac (Syzygium malaccense) in refrigerated storage. Postharvest Biol. Technol. 18:253-257.

Sherwin, H.W. and J.M. Farrant. 1998. Protection mechanisms against excess light in the resurrection plants Craterostigma wilmsii and Xerophyta viscosa. Plant Growth Reg. 24:203-210.

Smart, R.E. and T.R. Sinclair. 1976. Solar heating of grape berries and other spherical fruits. Agr. Meterol. 17:241-259.

Steyn, W.J., D.M. Holcroft, S.J.E. Wand, and G. Jacobs. 2003. Regulation of pear color development in relation to activity of flavonoid enzymes. J. Amer. Soc. Hort. Sci. 129(1):6-12.

Unrath, C.R. 1972. The evaporative cooling effects of overtree sprinkler irrigation on 'Red Delicious' apple. J. Amer. Soc. Hort. Sci. 97:55-58. 